\title{
Lighting Intensity Drop through Green Curtain
}

\author{
Jutarat Kaewngam, and Kuaanan Techato*
}

\begin{abstract}
This study had selected the plants to be the green curtain working as shading devices. The shading will block some solar radiation causing the reduction of the temperature of the wall outside the building. The shading is however reducing the lighting as well. The experiment had been done from March to August of 2015 to measure the lighting in front of the green curtain and the back of the curtain. The lighting was related to the Leave Area Index. For 6 months, the first kind of plant had grown up and the leave area index has increased from $7.30 \%, 8.53 \%, 9.15 \%, 10.70 \%, 10.99 \%$ to $11.16 \%$ whereas the second kind of plant leave area index had increased from $6.30 \%, 6.85 \%, 9.22 \%, 11.18 \%, 12.11 \%$ to $14.73 \%$. The lighting intensity dropped during $20-80 \%$.
\end{abstract}

Keywords-lighting intensity, green curtains, Thunbergia grandiflora (Roxb. ex Rottler) Roxb. and Mandevilla amoena cv.

\section{INTRODUCTION}

$\mathrm{T}$ HE sun, as a source of natural lighting, is the origin of energy which is important to the human and ecology. The solar radiation however brings the heat to the earth as well. The utilization of day lighting for the building has to trade off with the heat transfer to buildings. The installation of air-conditioner can adjust the room temperature but eject heat to the surrounding of the room (Cook, 1989). The reduction of the solar radiation to the building wall can also reduce the energy consumption of the air-conditioning system. The attempt to block the solar radiation by plants as green curtain can be a kind of shading device. The leave area is therefore important to the concept of shading. It is not only shading but also reflecting and absorbing. In view of growing up, the net amount of the Oxygen for plants is surplus. The net amount of Carbon Dioxide is deficit (Johnston and Newton 2004). The promotion of plants is a way of Carbon Dioxide reduction which leads to the term mitigation of global warming. The research aimed at the feasibility study of finding the relation between lighting intensity standard required level (Lux) and the leave area index of the green curtain. The result can be used as guideline of architects.

\section{METHODOLOGY}

The experiment was done at first floor of the 8-floor Faculty of Environmental Management, Prince of Songkla University as in Fig.1a.

Jutarat Kaewngam, and Kuaanan Techato*, are Faculty of Environmental Management, Prince of Songkla University.

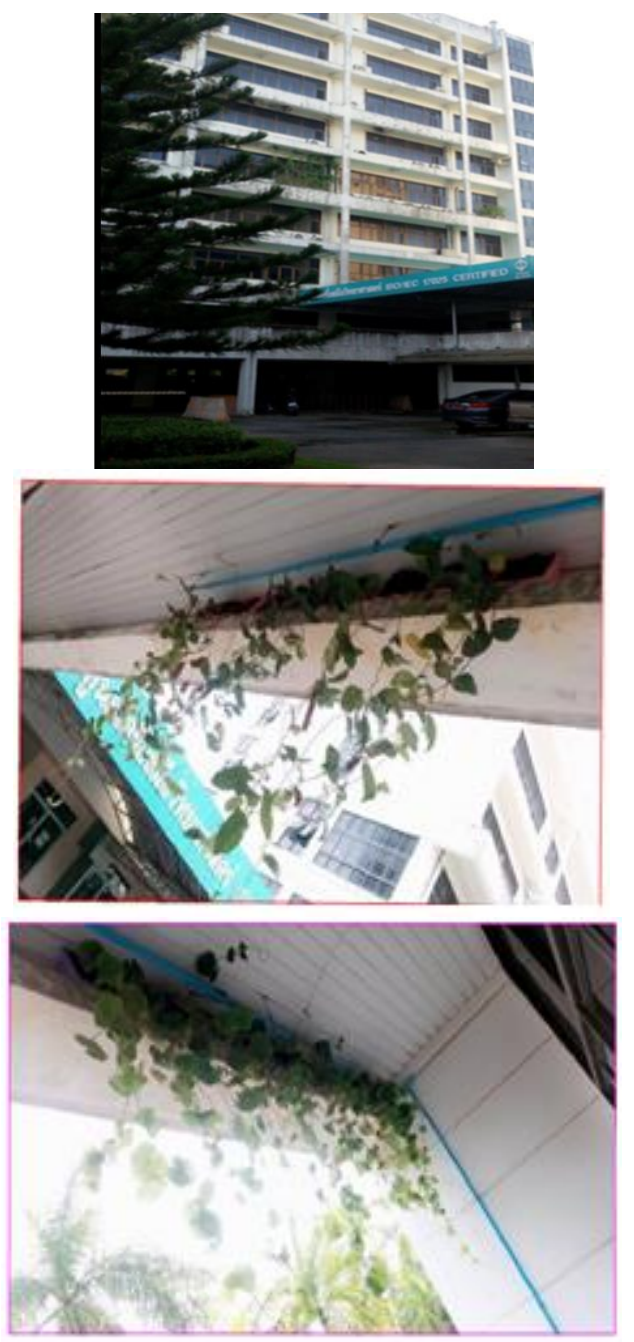

Fig. 1a, 1b, and 1c from left to right,

The 8-floor Faculty of Environmental Management and two plants used for experiment

Select the vine plant which can be hung itself in the vertical form as shading device of the building. The local plants were selected from five types to two types which has good growth rate, approximately $10-15 \%$ of leave area index to avoid the blocking of daylight from outside the building. Those two plants are Thunbergia grandiflora (Roxb. ex Rottler) Roxb. and Mandevilla amoena $c v$. Alice Du Pont as in Fig. $1 \mathrm{~b}$ and 1c. Plant the first type for E101 and the second type for E101A. The room E102 is the controlled room which has no plant. Record the intensity of light by lux meter at 09.00, 12.00, and $15.00 \mathrm{hr}$. from Monday to Friday for three months in summer (March to May) and three months in raining (June to August) in 2015. The point of measurement is in front of the plant, behind the plant and on the desk in the room close to the 
wall. The leave area index was estimated by the Autodesk Land Desktop 2006. The wind velocity, ambient temperature, ambient humidity, and rainfall were recorded as background of data.

\section{RESULT AND DISCUSSION}

Thunbergia grandiflora (Roxb. ex Rottler) Roxb. and Mandevilla amoena cv. Alice Du Pont had been used for heat reduction for 6 months (March to August 2015). The leave area indexes of each month of the plant Thunbergia grandiflora (Roxb. ex Rottler) Roxb. were 7.30\%, 8.53\%, 9.15\%, 10.70\%, $10.99 \%$, and $11.16 \%$ whereas the leave area index of plant Mandevilla amoena cv were $6.30 \%, 6.85 \%, 9.22 \%, 11.18 \%$, $12.11 \%$, and $14.73 \%$.

It is assumed that the heat had been reduced from the performance of leave in photosynthesis, evapotranspiration, and reflection (Wolverton et. al. 1989). The lighting intensity of each month was drop around $20-80 \%$ but not effect to the luminance in the room which is measured by lux meter showing all over 300 lux on the table.

\section{CONCLUSION}

The leave area index of plant around 5-15\% will not drop the luminance so much and still let the light go through the inside of the building enough for the general working with the 300 lux requirement.

\section{ACKNOWLEDGMENT}

This environmental management research was accomplished with support from the Faculty of Environmental Management, Prince of Songkla University. The financial support for the research was from the Energy Planning Policy Office, Ministry of Energy Thailand.

\section{REFERENCES}

[1] Chen J.M. and Black. T.A. (2007). "Defining leaf area index for nonflat leaves" Plant Cell and Environment 5, 23-35.

[2] Jeffery Cook. (1989). Passive Cooling. USA: MIT Press

[3] Jacklyn Johnston and John Newtom. (2004). Building Green A guide to using plants on roofs, walls and pavements. London: Publishing Greater London Authority

[4] B.C. Wolverton, A. Johnson and K. Bounds. (1989). Interior Landscape Plants for Indoor Air Pollution Abatement. 